\title{
Bringing Governance Back into Education Reforms
}

The Case of the Philippines

Kidjie lan Saguin and M. Ramesh

\section{(2) OpenEdition}

\section{Journals}

Electronic version

URL: http://journals.openedition.org/irpp/1057

DOI: 10.4000/irpp.1057

ISSN: 2706-6274

\section{Publisher}

International Public Policy Association

\section{Printed version}

Date of publication: 1 September 2020

Number of pages: 159-177

ISSN: 2679-3873

Electronic reference

Kidjie Ian Saguin and M. Ramesh, "Bringing Governance Back into Education Reforms", International Review of Public Policy [Online], 2:2 | 2020, Online since 01 September 2020, connection on 29 January 2021. URL: http://journals.openedition.org/irpp/1057 ; DOI: https://doi.org/10.4000/irpp.1057

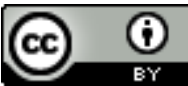

International Review of Public Policy is licensed under a Creative Commons Attribution 4.0 International. 


\section{Bringing Governance Back into Education Reforms}

\section{The Case of the Philippines}

\section{Kidjie Ian Saguin}

Lee Kuan Yew School of Public Policy, National University of Singapore

\section{Ramesh}

Lee Kuan Yew School of Public Policy, National University of Singapore. UNESCO Chair of Social Policy Design in Asia

\section{Abstract}

Educational systems around the world have undergone major reforms since the 1980s, with largely disappointing results. The objective of this paper is to understand the reasons behind the lackluster results with the purpose of devising ways to address them. Analysis in the paper is based on the understanding that the education sector is characterized by distinct functional imperatives that need to be addressed in policy responses that must involve a wide array of actors to be effective. In this view, education policy is fundamentally about establishing a governance structure to ensure that all the essential functions necessary to achieve the chosen policy goals are performed. Accordingly, the paper proposes a governance framework for education comprising political and operational functions, which it then applies to education policy reforms in the Philippines since the 1970s. The analysis finds that the reforms have focused on financing and decentralization issues while overlooking many other critical governance functions. The lackluster results are unsurprising given that the sector has been beset by many problems unrelated to centralized bureaucratic administration and which have been left unattended. The conclusions regarding the importance of comprehensive governance to emerge from this study are relevant not only for understanding education policy reforms in the Philippines and elsewhere but will also help develop a fuller understanding of the functioning of the education sector in general.

\section{Keywords}

education policy, governance of education, education reform, Philippines 


\section{Introduction}

Educational systems around the world have undergone major transformations since the 1980s, largely due to the growing recognition of the central role they play as a driver of economic and social development. In developing countries, the Millennium Development Goals, and its successor the Sustainable Development Goals, have played a catalytic role in pushing education reform to the center of development debates. However, most countries have been more successful at quantitative expansion of school places and attendance rather than providing quality education. We can look back to the experience of these countries to draw lessons from their experiences, especially regarding their efforts to implement the policy of universal education.

The objective of this paper is to analyze education policy reforms in the Philippines in recent decades, with the purpose of drawing generalizable conclusions about what works, in what combination, and to what extent. It starts by drawing attention to the critical failures that afflict the education sector and then proposing a framework for addressing them. It argues that the purpose of education policy must be to develop a governance framework to ensure that all necessary functions to achieve desired goals are performed. It then applies the framework to the case of education policy reforms in the Philippines. The study finds that the reforms have focused largely on mobilizing additional resources and decentralizing management. While the measures did address some critical governance imperatives, they overlooked many governance arrangements necessary for the reforms to succeed. Given the critical governance deficiencies that remain unattended, Philippine's mediocre educational performance is hardly surprising.

\section{Education Reform}

Education systems are one of the most complex systems of organization in the public sector, making reforms and innovations particularly complicated. The very nature of the sector - the variety of stakeholders, differences in time horizons, and unpredictability and immeasurability of results - sets it apart from other services (Cerna, 2014). Education bureaucracies are typically seen as difficult to reform because they are "multitask, multi-principal, multi-period, near-monopoly organization[s] with vague and poorly observable goals” (Dixit, 2002, p. 719). Observers have long characterized education systems as 'loosely coupled systems' or 'organized anarchies' (Weick, 1976), where "authority and power are distributed among well-defined institutions at different levels” (Kogan, 1975, p. 231). Such weakly but interdependent connections between units are typically seen as caused by unclear means-end connection and fragmented internal and external environments (Orton \& Weick, 1990), not by conscious strategy but as a product of adaptation to the varying pressures on the organization manifested as 'organizational foolishness' (March, 1981). These characteristics of education systems, including the inherent path dependency associated with its socio-political value in nation-building (Szolár, 2015; Tan \& Yang, 2019) and interdependence with other components of the social system (Paterson \& Iannelli, 2007), make education reforms particularly hard to pull off.

Policymakers have nonetheless embarked on education policy reforms that either reallocate existing spending to more productive areas of education, introduced financing schemes to fill gaps, and/or re-configured managerial and institutional arrangements (Tiongson, 2005). These reforms are distinct from the typical curricular reforms or professional development interventions pervasive in the sector because they affect the distributional impact of education by shaping how education services are delivered rather than what is delivered (Egalite, Fusarelli, \& Fusarelli, 2017; Wong, 1994). The types of education reform also vary by the measures implemented: rules, resources and incentives (McDonnell \& Elmore, 1987). Rules and 
mandates are important in establishing the scope of authority of central administration and their span of control in ensuring that all units adhere to similar standards. It is believed that resource constraints inhibit the ability of education professionals to deliver educational services, supported by adequate classrooms, qualified teachers, and sufficient textbooks that are conducive to learning. Incentives are also equally crucial as studies show policy measures like cash and transfer programs influence household behavior by keeping children in school who would otherwise engage in child labor (Baird, Ferreira, Özler, \& Woolcock, 2014).

The wide range of actors involved in education, depicted in Figure 1, complicates efforts to reform it. Education, after all, "is produced by business enterprise and by households, as well as by government; it is partly produced outside the market altogether" (Rivlin, 1973, p. 413). Governments have attempted to generate information about the actual production process of education services, the characteristics of the product in so far as how learning occurs, and the behavior of different actors involved in the delivery of education (Hannaway \& Woodroffe, 2003). As shown in Figure 1, schools lie at the heart of education service delivery and many countries employ a private-public mix school system. Their relations with the government and households differ depending on school ownership. The government sets standards and regulations for all schools but provides different levels and forms of funding for public and private schools. Households are co-producers of education and pursue their interests by exercising choice between private and public schools. They also make the government accountable, primarily through elections but also increasingly through school management bodies of various sorts.

Figure 1. Actors and Relationships in Education Governance

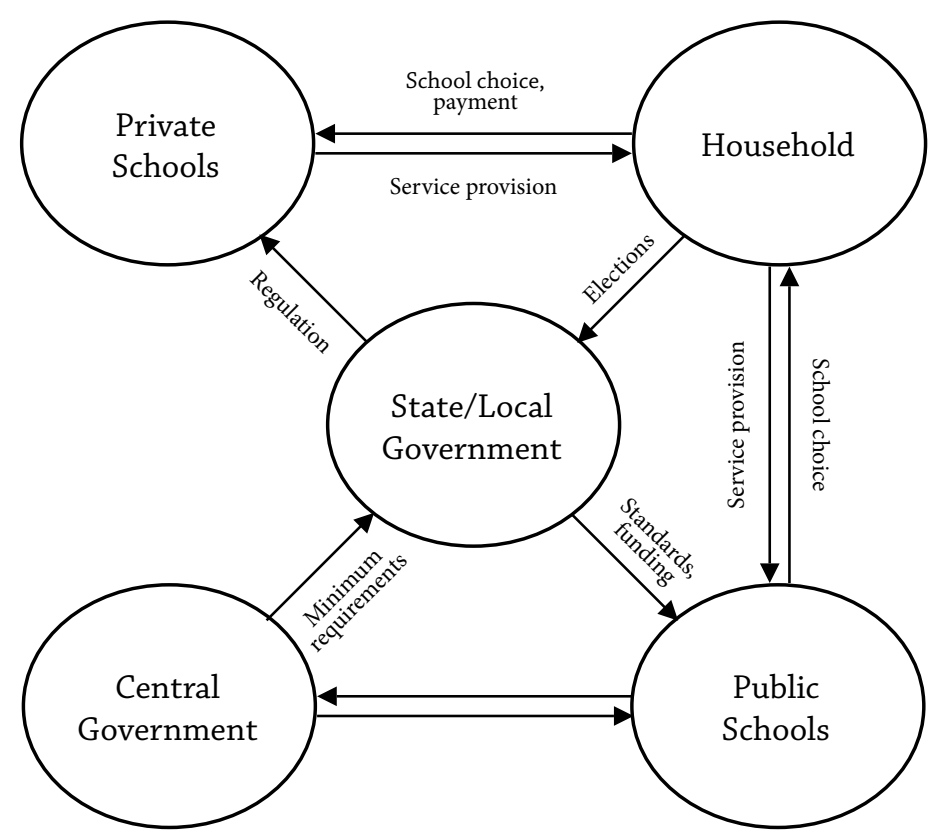


Intervening in such a complex policy sector makes for an uncertain policy environment and only limited scope for complete success. Thus, even reforms successful at improving enrolment, attendance and progression do not necessarily lead to improvement in test scores and achievement outcomes (Petrosino, Morgan, Fronius, Tanner-Smith, \& Boruch, 2012). Similarly, decentralization efforts like school-based management (SBM)have been shown to reduce repetition rates and student failures, but evidence is mixed regarding their effects on academic achievement (Patrinos \& Fasih, 2009). Pious hopes aside, there is no reason to assume that schools will perform the required functions simply because they have been conferred decision authority, as assumed by proponents of decentralization. As Chapman puts it, "[d]ecentralization is not an automatic solution unless decision making reflects a clearly defined division of authority and responsibility between different levels of the system" (Chapman, 2000, p. 302). The school management needs to be given clear direction, backed by appropriate incentives and rewards, if they are to achieve their objective.

What is needed, first of all, is a coherent conceptualization of a comprehensive governance framework for education. Many scholars have rightly called for bringing together the theories of public policy with education policy to fully understand and address the challenges faced by the sector (Grace, 1995; Whitty, 2002). Yet, there is little theoretical work offering systematic definition of education policy or education system reforms. Education system is often understood to mean anything that pertains to the design and implementation of education - laws, rules, administrative offices, personnel, and instructional materials. In this view, educational policy refers to any intervention that affects the education system, with the notion of 'policy' borrowed from policy studies without due understanding of its purpose (Corson, 1986; Ranson, 1995). These wide-spanning and catch-all conceptualizations have spurred limited theoretical debates about how best education systems should be configured or how education policies should be designed.

Traditionally, educational policy interventions were designed to shape how learning occurred in the classroom and often ignored the policy and implementation aspects of education. Early reforms in the US, for example, were inspired by perceptions of a 'crisis of teaching' despite the absence of strong empirical evidence supporting this perception (Weis, 1987). Education policy is not only about "the statements of strategic, organizational and operational values (product) but also the capacity to operationalize values (process)" (Bell \& Stevenson, 2006, p. 18). Thus, from a policy perspective, education reforms can be conceived as the changes in objectives and organization of the education system as well as the capacity to carry out the intended changes (Bowe, Ball, \& Gold, 2017). Since education is inherently multi-dimensional, multi-objective and multi-principal, policy reforms are unavoidably intertwined, with goals and implementation strategies typically layered and woven together (Helgøy \& Homme, 2006). This points to the importance of analyzing the elements of education reform as a whole rather than as discrete strategies or measures. Education reforms are also necessarily political, as they produce winners and losers (Levin, 2001).

From this perspective, education policy is fundamentally about establishing a governance structure to ensure that all the essential functions necessary to achieve the chosen policy goals are performed. This is aligned with the 'governance turn' in education, where transformation in systems involves changes in structures, participants, discourse and 'subjects' (Ball, 2009). However, while actors play a huge role in governance, as suggested by existing notions of decentered governance (Bevir \& Rhodes, 2003, 2006) or interpretivist governance (Rhodes, 2012), the choice of the structural relationship between the government and non-government actors - as in legal, 
market, network or corporatized - is an important determinant of governance effectiveness (Capano, Howlett, \& Ramesh, 2015). Effective governance of education can be designed by examining how these actors can meaningfully work together to address key governance failures (Saguin, 2019). Education reforms thus involve effecting changes to the governance functions, including funding, provision, ownership and regulation (Dale, 1997). Using Kooiman's (2000) framework of distinguishing socio-political interactions based on 'governing orders', education reforms inevitably alter the management of day-to-day affairs (operational functions) as well as meta-governance (political) framework for how 'governors are governed'.

\section{Framework for Understanding Education Reforms}

While the goals of education are diverse and controversial, the goals of education policy are, at the core, more straightforward, centered on establishing governance processes to guide the key stakeholders' behavior in a desired manner. Effectively designing education policy involves identifying the necessary governance functions - which may be grouped as political and operational - that must be performed and establishing institutions and processes to ensure they are performed. The specific functions and mechanisms vary across jurisdictions and over time, of course, but they share substantive core conditions. A generic framework, which will be applied subsequently to the case of the Philippines, is outlined in Table 1.

Table 1. Critical Governance Functions in Education

\begin{tabular}{|l|l|}
\hline Political & Operational \\
\hline - Setting direction, goals and objectives & $\begin{array}{l}\text { - Designing and deploying } \\
\text { appropriate policy tools }\end{array}$ \\
\hline - Mobilizing resources for achieving goals & $\begin{array}{l}\text { Managing financial and } \\
\text { human resources }\end{array}$ \\
\hline $\begin{array}{l}\text { Building political support and establishing } \\
\text { collaborative arrangements }\end{array}$ & - Ensuring accountability \\
\hline $\begin{array}{l}\text { Allocating powers and responsibilities to ap- } \\
\text { propriate units and levels of the government }\end{array}$ & - Designing appropriate curriculum \\
\hline
\end{tabular}

Source: The Authors

A crucial political policy function in education, indeed any sector, is to set the overall strategic direction and goals and the medium- to short-term objectives: what is it that the government seeks to achieve through its policy measures and within what time frame? Is it to provide essential education to all, reduce regional or socio-economic disparities, or train a work-ready workforce, and so on? While these are not necessarily mutually exclusive goals, not all can be pursued simultaneously, at least not easily and not in the medium to short term due to practical difficulties (Mintrom, 2001). Next, it is important for governments to mobilize the fiscal and political resources necessary to support the measures being taken to achieve the goals.

While providing basic education to all children is within the fiscal means of most governments, higher quality education requires better facilities and better paid teachers, which requires additional resources that often must come at the expense of other sectors. Without belabor- 
ing the definition of quality, which has been debated and discussed elsewhere (Cheng \& Tam, 1997; Harvey \& Green, 1993; Hoy, Bayne-Jardine, \& Wood, 2000), the term is taken here to mean the development of a range of socioemotional, technical, and physical skills that allow individuals to be productive and innovative (World Bank, 2018). Similarly, objectives such as promoting equity or national integration require political will and capacity to counter likely opposition from groups who do not benefit and may even lose out. Finally, governments need to strengthen their links with societal partners and enjoy their trust and support to push through politically difficult measures (Zajda, 2003). Many reform efforts around the world flounder in the face of opposition from teachers' unions and apathy from the population (Strunk \& Grissom, 2010). Successful reforms also need the support of business, who can contribute finances as well as labor market information for education. As such, political alliances between the government and civil society are essential for effective education policy reform.

Ensuring that the right levels of government are tasked with the appropriate responsibilities is a vital governance function (King \& Guerra, 2005). Strategic direction and goals, for instance, must necessarily come from the highest level of the government, while local governments and service delivery units (i.e. Schools) must set their own operational objectives aligned with overall goals. The overall responsibility for mobilizing fiscal and political resources is similarly the responsibility of the central government, even in situations when education spending is the responsibility of local governments. Without such an arrangement, local governments with weak finances, tenuous political support, or low policy capacity will be left behind. Education, similar to other complex sectors, requires a modicum of collaboration across agencies and with partners that is best undertaken at the local level, whereby families, businesses, and teachers collaborate to achieve goals and objectives (Han \& Ye, 2017).

Most operational functions - policy tools, accountability mechanisms, and fiscal and personnel systems - are the responsibility of regional governments, though central and local governments are intricately involved. As such, the regional governments need to be given the responsibility and commensurate financial and other resources to perform the actions.

The overwhelming emphasis on across-the-board decentralization in education reforms in many countries has skewed reform efforts and produced unsatisfactory results. Even a decentralized system requires the national government to 'steer' the education sector not only through the traditional mechanisms of curriculum, operating procedures, and accountability requirements, but also through performance monitoring and evaluation (Daun, 2007; Karlsen, 2000). Bardhan (2002) rightfully argued for the national government to take on 'activist roles' such as mobilizing citizens and providing technical assistance and coordination of localities to mitigate the negative outcomes from decentralization. A strong measure of central direction is also necessary to mitigate regional disparities and prevent rent-seeking behavior by local governments (Ozga, 2009). However, performing these activities requires a certain ability to acquire and process information and data to understand where interventions are necessary (Cohen \& Levinthal, 1990; Ouimet et al., 2010).

The intermediate level of government is expected to localize national priorities and direction based on the local setting through consultations and bargaining with other actors such as local politicians and local counterparts of national government agencies. Establishment of field administration is especially critical where tasks and responsibilities are geographically distributed through deconcentration (Fesler, 1968; Rondinelli, 1981). Those at the intermediate level are typically expected to carry out inspection and monitoring as well as offer pedagogical support, technical advice, capacity building of local staff, and performance evaluation (Daun, 
2007). As an intermediator, units at this level of administration require high levels of analytical capacity to localize policies and standards but only require moderate levels of managerial capacity since intermediate levels are responsible for budgeting but are not delivery units. They should also have medium level of political capacity because of the need to create vertical integration of programs with both the national and local levels and horizontal coordination with other agencies and regional politicians.

Once the government has set the political direction and mobilized resources and built support for the reform measures, it needs to put them in operation, which comprises numerous interrelated and intertwined tasks. Significant failures to perform these tasks will trip the reforms and, indeed, it is through failure in this area that reforms often go awry.

The first task is to plan the delivery of the new programs and adjust the existing program as necessary. In education, in addition to curriculum issues, there is the vital task of designing the organizational structures and their roles, powers and responsibilities (Altrichter, Heinrich, \& Soukup-Altrichter, 2014). This is perhaps the most important operational task because assigning tasks to wrong agencies or insufficiently clarifying the relationships among them would stymie concerted action. It is in this broader institutional context that SBM needs to be conceptualized, and not as a separate reform, as is commonly the case. Another critical operational task is to design necessary rules, regulations, and standards to control agencies' and their officials' behavior, accompanied by appropriate incentives and disincentives to reward and improve performance (Hannaway \& Woodroffe, 2003). Similarly, the concerned agencies need to be allocated the financial and personnel resources necessary to acquit themselves of their responsibilities backed by a robust budgeting and personnel system. Finally, it is critical to establish robust accountability mechanisms for monitoring, reviewing and auditing performance, and meting out rewards and penalties as appropriate. All of the other efforts may come to naught if agencies and their officials realize that there are no penalties for poor performance and no rewards for exceeding expectations.

Designing and operating a modern education system is a complex task and involves immense challenges, the overcoming of which requires sophisticated analytical work on the part of policymakers. Designing an appropriate curriculum so that children receive the intended education, for example, requires analyzing vast data and drawing policy-relevant conclusions about them. Effective education policy also requires data and analysis of trends regarding educational achievements, equity, productivity, human resource needs and so on, all of which require elaborate and complex analytical tasks. The vital and growing importance of analytical skills and resources is yet to be fully understood and addressed in most governments.

\section{Research Method}

Using a single-case study method (Yin, 1981), this paper examines education policy reforms in the Philippines using the framework set out above. Based on archival data and expert interviews, observations are constructed diachronically as a way to tease out within-case variation that may have led to the existing set of education outcomes in the country (Gerring, 2006). In June 2016, a total of seven (7) elite interviews were conducted with executives of the Department of Education (DepEd) in the central, regional and district offices as well as at a school. The respondents were identified by DepEd based on who can provide the most relevant information about how governance reforms are undertaken in the Department. As the research was largely exploratory, the purpose of the data collection was to help construct an "analytically generalizable" (Yin, 2009) framework to guide future governance reforms in education by other governments. 


\section{Education Policy Reforms in the Philippines}

The Philippines represents a critical case for testing the comprehensive governance framework. Largely understudied in the education literature, the Philippines was an early leader in expanding school education in Asia and indeed the developing world, but it lost the lead during the 1970s and 1980s when social development stagnated along with economic growth and political competition. At the turn of the $20^{\text {th }}$ century, the Philippines sought to establish universal primary education and by the 1960s was "already ahead of most other colonies in popular education" (Myrdal, 1968, p. 1632). The end of dictatorship and the onset of democracy in the late 1980s fostered pressure for improving the quality of education for all children. The government responded with broad sets of measures, including decentralization of education administration (De Guzman, 2007), over successive periods, with mixed results. The country managed to pass key legislation to universalize kindergartens, extend the basic education cycle from 10 to 12 years, and institutionalize mother-tongue based learning. Yet the quality of education remained and remains a concerns, confirmed by the recent OECD-PISA results, which put the country among the lowest of all those covered by the assessment (Schleicher, 2019).

Philippine government leaders have over the decades declared education to be one of their top policy priorities and devoted considerable resources to the sector. However, beyond expressing general commitment to promoting education, the government has offered little clarity about its goals or the means to achieve them. Instead of viewing the sector holistically and addressing the need to perform the diverse governance tasks that must be performed in concert, it has employed decentralization as a multi-purpose and omnipotent tool for achieving its disparate objectives despite pervasive evidence of this approach's limitations. The singular emphasis on decentralization and neglect of other necessary reforms lie at the root of poor education outcomes in the Philippines, as we will see in this section.

Table 2. Education Indicators, Philippines (1975-2015)

\begin{tabular}{|l|l|l|l|}
\hline Key Indicators & $\mathbf{1 9 7 5}$ & $\mathbf{1 9 9 5}$ & $\mathbf{2 0 1 5}$ \\
\hline - Net Enrolment Ratio (Primary) & $96.79(1976)$ & $95.68(1996)$ & 95.72 \\
\hline $\begin{array}{l}\text { - Gross Intake Ratio to the last } \\
\text { grade of primary education }\end{array}$ & $85.81(1981)$ & $84.70(1998)$ & 100.52 \\
\hline - Net Enrolment Ratio (Secondary) & $46.19(1979)$ & $57.93(1996)$ & 65.92 \\
\hline $\begin{array}{l}\text { Gross Intake Ratio to the last } \\
\text { grade of secondary education }\end{array}$ & $1.71(1980)$ & 3.04 & $71.27(2013)$ \\
\hline $\begin{array}{l}\text { Govt Expenditure on } \\
\text { Education, \% of GDP }\end{array}$ & $68.40(1992)$ & 2.7 \\
\hline
\end{tabular}




\section{Setting Goals, Directions and Objectives}

Universal quality education has been the stated goal of successive governments in the Philippines for decades, long before it was enshrined in the constitution in 1987. Yet no government has clearly spelled out a practical vision of how the goal is to be achieved. In fact, the problem of a lack of operational and achievable objectives was recognized as early as the 1970s: "The present objectives prescribed for Philippine education which are really goals of the entire social system, and are, therefore, unachievable aims for the educational system alone" (Presidential Commission to Survey Philippine Education, 1970, p. 2).

Efforts to clarify basic education policy objectives have proven insufficient despite identification of clearer operational strategies. Defined in the K-12 law of 2012, education policy now seeks to develop a "productive and responsible [citizen] equipped with the essential competencies, skills and values for both life-long learning and employment". However, the basic education bureaucracy sets itself up to fail when the policy objective reflects the goals of the entire education system (to include vocational and higher education), that is, to bestow functional literacy. Since performance of the basic education sector is typically measured in terms of efficiency (e.g. completion rates) and quality (e.g. achievement rates), what appears to be a more instructive of the problems (i.e. access and quality) basic education policy aims to address are the ones outlined by DepEd's organizational outcomes: a) Access of every Filipino to a complete quality basic education achieved, and b) Preparedness of every graduate for further education and world of work ensured.

\section{Building Political Support and Collaborative Arrangements}

Like their East Asian neighbors, Filipinos value education primarily because of the belief that it is the main determinant of better employment and income prospects. Based on the Nielsen Global Survey of Education Aspirations in 2013, 90\% of Filipinos correlate quality of education with better opportunities in the workplace, compared to a global average of $75 \%$. In 2016, Social Weather Station (SWS) also found strong support from the public for providing more funds for education. It is therefore unsurprising that education policies feature prominently among legislators' political agenda, with $44 \%$ of the bills filed on the $16^{\text {th }}$ Congress in the House of Representatives coming from the Committee on Basic Education and Culture.

The breadth of support for education has made it easy to mobilize stakeholders to contribute to the attainment of stated goals. The K-12 reform that began in 2010 was necessitated by the need for a calibrated effort on the part of the three education agencies - DepEd, Commission on Higher Education (CHED) and Technical Education and Skills Development Authority (TESDA) - to lead a multi-sectoral advisory group. Curriculum reform required collaboration between the CHED and TESDA to determine what competencies are articulated in basic education from university and vocational education. Identifying competencies needed by industry necessitated working with the labor department and various industry organizations. The actual extension of the education cycle also meant that colleges and universities would almost have zero enrolment for two full years, but associations of private universities remained largely supportive of the initiative. All these arrangements required a macro-level view of how reforms unravel and how stakeholders can be engaged to push it forward.

But such ease in building support is only contingent on the ability of the education bureaucracy to coordinate the introduction of reforms. The typical mandated nature of coordination between the different education agencies indicates an environment deficient of regular harmonization of policies and programs. As a result of education tri-focalization, setting up the 
sub-sector education goals required mobilizing different stakeholders at different levels of the government, prompting various administrations to create special coordinative bodies to 'harmonize [the] goals and objectives' of the education system, such as Joseph Estrada's Presidential Commission on Educational Reform and Gloria Arroyo's National Coordinating Council for Education (NCCE). Such ad hoc and sporadic efforts undermined the government's capacity to implement reforms in a coordinated manner.

\section{Mobilizing Resources}

Early on, the political leaders realized that education objectives can only be achieved with ample supply of fiscal resources. A provision in the 1987 Constitution mandated the government to "assign the highest budgetary priority to education" to guarantee the right to quality education of all citizens at all levels. The provision addresses low spending on education. The share of education spending in total national spending declined from $31.53 \%$ in 1957 to $7.61 \%$ in 1981 , before rising again to $16 \%$ in 1987 (Dolan, 1993). More recently, education spending stayed within the range of $13 \%-18 \%$ of the total budget from $2009-2017$.

Historically, financing education has posed a major challenge to enacting reforms. Because of unstable national budgeting processes, local governments have been mobilized as supplementary financing for construction and operations of schools since the early 1960s. In 1991, local governments were required to allocate $1 \%$ of the real property tax revenues to a Special Education Fund (SEF). This boosted local government spending on education from P0.8 billion in 1991 to P7.9 billion in 1998 (Behrman, Deolalikar, \& Soon, 2002). By 2008, SEF expenditure as a percentage of non-personnel expenditure on education was $41 \%$ (Manasan, Cuenca, \& Celestino, 2011), suggesting a significantly larger contribution of local governments on education than originally conceived.

Despite this, additional financing was needed to fill in the input gaps, particularly classrooms. Since 2012, the private sector, through public-private partnerships (PPP), has constructed more than 10,000 classrooms, amounting to a monetary value of Php19 billion. International financing institutions also provided loans, such as one of approximately $\$ 300$ million from the Asian Development Bank in 2011.

\section{Allocating Powers and Responsibilities to Appropriate Levels of Government}

The history of administrative decentralization of education in the Philippines clearly highlights how decisions about organizational forms, despite good intentions, are often misguided. Allocating powers and responsibilities to different units and levels of government revolved around expanding the scope and depth of decentralization of functions in the hope that local governments will use their autonomy to address access and quality problems in basic education rather than on the basis of assessment of which level is more appropriate for assuming the responsibility. While centralization was critical in meeting the need to quantitatively expand the system during the American occupation and after the Second World War, coordination of public service provision did not keep up with the rapid expansion of the education system, particularly in rural areas (Zamora, 1967). Because of these constraints, political decentralization has long been identified as a suitable structure to better achieve the qualitative objectives of education (Swanson, 1960; UNESCO, 1949). Schools were progressively granted some degree of autonomy, formalized only through the Governance of Basic Education Act of 2001, which assigned functions to each level of education bureaucracy from the national level to the school level. 
However, different levels of local government have been allocated functions regardless of their capacity or incentive to perform the assigned functions. Schools' for example' struggled with the newly conferred financial responsibilities entailed in allocating, spending and liquidating operational expenses, a core principle of School Based Management (SBM). Subsequent recentralization of control over school improvement funds indicates an allocation of roles based on faith rather than actual capacity. Local governments were also brought in to provide local financing to school operations but the special education fund utilization remained very limited, owing to a faulty budgeting process that is both at the mercy of national and local governments (Manasan et al., 2011).

The process of decentralization has also been hijacked by existing officials, leading to sub-optimal allocation of functions. Despite the percolation of political decentralization of education into the earlier organizational forms, the decentralization that eventually occurred was what Brillantes (1987) called a 'department model' of administrative decentralization. Policy legacy would have guaranteed the devolution of education to the local governments, but backroom negotiations by the education bureaucracy resulted in the exemption of education from decentralization (Diokno, 2008). Regional and division offices that are at the mercy of a rigid national budgeting process continue to dominate the process of making decisions that clearly affect school management (De Guzman, 2007). As a former DepEd senior official lamented, "[r]egional offices...continue to try to control situations making operational decisions that are best left to school divisions" (Luz, 2009, p. 12).

\section{Designing Policy Tools}

The lack of acumen in designing and deploying is evident in DepEd's inability to move away from the traditional command and control tools to use more nimble newer tools for promoting accountability and performance. The criticisms over DepEd's 'culture of obeisance' (Bautista, Bernardo, \& Ocampo, 2009), the 'no memo, no action attitude' (Monsod, 2009) and the governance by 'DepEd memo' (Luz, 2009) point to the very top-down and heavy-handed approach in getting things done within the education organization. As a result, most of DepEd's policies have excessively focused on easily measured and controlled activities (Monsod, 2009) as the central office is heavily engaged in directing and guiding the day-to-day affairs of regional and division offices. Such a culture only perpetuates the slow and incremental transformation of reforms into results.

Even the introduction of market-based policy instruments by DepEd has been constrained by this culture of obeisance. The education service contracting (ESC) scheme, one of the largest public-private partnership programs in the world ( Patrinos, Barrera-Osorio, \& Guáqueta, 2009), was introduced to democratize and improve access to quality education for 'poor but deserving' high school students by providing grants to students to attend private high schools to shift them away from congested public high schools. Recent evaluation studies of the scheme have demonstrated the failure of the scheme to decongest the public secondary school system and provide greater access to needy students (Philippine Comission on Audit, 2018). The ESC failed to properly align the grants or slots with the distribution of 'aisle students' (or those students in excess of the current capacity of schools) (World Bank, 2011). The main source of the setbacks is the inability of DepEd to construct an institutional arrangement that aligns the interests of the private administrator of ESC (i.e. the Private Education Assistance Committee/PEAC) and the equity objective of the scheme. As pointed out by the World Bank (2011), DepEd exercises almost no supervision over PEAC and is indeed subject to regulatory capture by it. Despite DepEd's willingness to employ market-based instruments, its lack of capacity to 
design appropriate policy tools and over-all proclivity for control mechanisms have contributed to the failure of the ESC.

\section{Managing Financial and Human Resources}

Despite efforts to guarantee sufficiently available resources, managing the largest bureaucracy in the country is not easy, particularly when it comes to expending financial resources and allocating personnel properly. For many years, DepEd has been unable to use its resources optimally, having a consistently low utilization of the budget at year-end. From 2012-2016, average year-end budget utilization rate ${ }^{1}$ was only $73 \%$, with the lowest rate recorded in 2013 (57\%). According to current and former DepEd officials, much of the underspending is a result of the inability to carry out planned procurements and failure to liquidate expenses at the field level. In 2016, the external audit reports showed gaps in program planning and implementation, particularly in procurement and sub-allotment of the Central Office to the Regional Office, eventually leading to non-utilization of the budget and budget reversals.

Chronic underspending is also evident in the schools. In 2008, a total of Php135 millions of school improvement funds were not downloaded to schools despite the thrust to automatically and directly transfers to field offices. The Philippine Commission on Audit report identified the failure of schools to prepare simple administrative documents like a School Improvement Plan and Work Program and financial reports as the primary reasons for the lack of downloading, indicative of many schools' unpreparedness to properly disburse funds. Many of the cash advances taken by division offices remained unliquidated or unutilized owing to the lack of training on how to correctly manage and record financial accountabilities.

Much of this inability to manage resources emanates from a lack of qualified managers at the different levels of the government. Appropriate supervision of schools is also largely absent owing to an insufficient number of division superintendents, with only $61 \%$ of divisions led by a duly-appointed superintendent in 2016, down from $80 \%$ in 2009 . The absence of division leadership has prevented the highly centralized structure from providing technical assistance and advice to its delivery units. The career system has also failed to generate adequately trained school administrators since school leadership is usually given as a token of seniority and not based on managerial potential (Luz, 2009). Only 65\% of elementary schools had either a principal or school head in 2016 (DepEd 2017). With all these issues considered, why SBM failed is unsurprising.

\section{Ensuring Accountability}

Until recently, there was no clear mechanism to hold the education department accountable for underperformance. DepEd adopted the Quality Assurance and Accountability Framework (QAAF) in 2010, defining accountability as vertical alignment of roles and responsibilities and allocation of principal accountability for certain education outcomes across different levels of the organization. However, implementation remains patchy, and as Ogundele and Laguador (2017) argue, proper assessment and evaluation can only be made after the implementation and roll-out of the quality assurance system. Recent government-wide reforms on improving performance management attempt to establish accountability through a single results-based performance management system (RBPMS), linked with a bonus system based on the performance of delivery units. A survey of perceptions of civil servants revealed that better management, trust and teamwork in DepEd as well as positive effects on teacher recruitment are the key results of the RBPMS (World Bank, 2014).

1 - Utilization rate is defined as total disbursement over total obligations. 
Driving accountability is challenging because of the situation of extreme scarcity of resources faced by different actors in the organization, particularly schools. Under the QAAF, schools serve as the core unit of quality assurance as they deliver the curriculum and instructions, teaching and facilitation, administration and leadership, learning environment and culture, while school performance is evaluated based on student achievement scores, dropout rates, the liquidation rate of maintaining expenses, and the achievement of other exemplary indicators such as demonstrating initiative and uniqueness under the RBPMS. However, there is widespread opposition to the performance management from the teacher's union because many teachers and principals see the lack of resources as a failure of the central government to provide support. School performance is thus perceived to be beyond the control of teachers (Torneo, 2016).

More importantly, the lack of trust in performance information exacerbates the performance paradox in basic education due to deep-seated corruption in DepEd (Reyes Jr, 2007; Reyes, 2009). In 2001, instances of cheating and selling of exams plagued standardized achievement exams, which led to the cancellation of the National Achievement Test (NAT). While the exam has since been reinstated, the same issues arose when an investigation by the National Bureau of Investigation revealed widespread cheating in 2011. More recent attempts to improve the integrity of information from DepEd involve systematization of data collection and management through database systems - the Enhanced Basic Education Information System (EBEIS) and the Learner Information System (LIS) — that primarily provide data and information on schools and learners. The EBEIS covers indicators of input performance such as number of teachers and number of schools, while the LIS uniquely identifies all learners in the education system, including information on gender, and name of guardian, among others. The LIS is envisioned to include information on achievement results and other performance data. The installation of the EBEIS has eventually led to the calculation of public school capacity and determination of aisle students that can be targeted for ESC (World Bank, 2011).

\section{Designing Appropriate Curriculum}

The education research generated within DepEd has no doubt directed reforms towards curricular issues; however, while most curriculum issues are known, the implementation of reforms has been dismal. Various educational assessments commissioned by the government have touched on broad issues to include sector governance, but curriculum improvements have been at the center of most reforms. As noted by the World Bank and Asian Development Bank (1999), curriculum design improvements that had been introduced earlier, such as reduction in subjects and reduction of contact hours, provision of inputs and re-design of implementation structure, continued to lag. In fact, much of the design issues, such as overcrowding of topics and overlapping and duplication of contents (Mariñas \& Ditapat, 1999), have been addressed and implemented on a larger scale only recently through the K-12 reform. The principle in curriculum design followed by the reformers was to ensure integrated and seamless learning, whereby lessons are horizontally articulated across subjects (Alonzo, 2015). These are thought to be the appropriate curriculum designs considering the initial problems faced by the disjuncture in instruction and curriculum between primary and secondary education due to a disjointed organizational structure.

One reform where DepEd has shown analytical capacity to design appropriate curriculum is the institutionalization of kindergartens and the introduction of mother-tongue based education. The Kindergarten Act of 2012 (otherwise known as Republic Act No. 10157) institutionalizes pre-elementary schooling as the first phase of mandatory and compulsory formal 
education, which is a response to years of research linking dropout rates, grade repetition and poor achievement rates to inadequate preparation for elementary education (Magno, 2010). The existing pre-elementary programs were so lacking in quality that, as the former DepEd Secretary Jesli Lapus noted, students need to "'un-learn' some of the things they were taught during their preschool year" (Lapus, 2008). The law also institutionalizes the adoption of a Mother Tongue-Based Multilingual Education (MTB-MLE), whereby the mother tongue of a child shall be used as the primary medium of instruction in classrooms. This came as a result of various studies employed by DepEd to distill best practices from other countries in improving the curriculum.

\section{Conclusion}

Over the last few decades, education systems around the world have been the subject of incessant reforms - centred on curriculum, teacher training, budget mobilization, SBM, decentralization, and so on - with varying but largely lacklustre results. In retrospect, the outcomes are unsurprising given that the reforms have focused on specific problematic issues without considering the relationships among them. More significantly, without a comprehensive conception of the sector and the requirements for its effective functioning, the reforms have been either partial or misdirected. This paper sought to overcome the lacunae in both scholarship and practice by proposing a composite framework identifying the key political and operational functions in the management of the sector and assessing the extent to which they are performed. From this perspective, education policy is fundamentally about establishing a governance structure to ensure that all political and operational functions necessary to achieve the chosen policy goals are performed.

Application of the framework to the case of the Philippines showed that while the reforms correctly identified and hit some of the targets, they overlooked, neglected or mishandled many more. The government's overwhelming focus on fiscal mobilization and, especially, decentralization, blindsided it to other vital governance functions. More crucially, the government has been unclear about education policy goals and how to achieve them. Resource mobilization and decentralization measures in the absence of goal clarity understandably produced only limited success. Similarly, political support for education did not realize its full potential due to an absence of clear operational objectives. The problem was compounded by lack of attention to analytical and operational functions that need to be attended to if the sector is to function effectively.

While decentralization and SBM reforms have provided much needed relief from the rigidities and unnecessary centralization of the past, they have had only limited impact due to shortcomings along other dimensions of governance. These unremarkable outcomes are hardly surprising given that neither decentralization nor SBM directly address many of the core governance deficiencies in the sector. It is hoped that further research along the lines proposed in this paper will encourage scholars and policymakers to focus more on strengthening governance of the education sector.

\section{Bibliography}

Alonzo, R. I. (2015). Understanding the K to 12 Educational Reform. Philippine Social Sciences Review, 67. 
Altrichter, H., Heinrich, M., \& Soukup-Altrichter, K. (2014). School decentralization as a process of differentiation, hierarchization and selection. Journal of Education Policy, 29(5), 675-699.

Baird, S., Ferreira, F. H., Özler, B., \& Woolcock, M. (2014). Conditional, unconditional and everything in between: a systematic review of the effects of cash transfer programmes on schooling outcomes. Journal of Development Effectiveness, 6(1), 1-43.

Ball, S. J. (2009). The governance turn!. Journal of Education Policy, 24(5), 537-538.

https://doi.org/10.1080/02680930903239904

Bardhan, P. (2002). Decentralization of governance and development. The Journal of Economic Perspectives, 16(4), 185-205.

Bautista, M. C. R. B., Bernardo, A. B., \& Ocampo, D. (2009). When reforms don't transform: Reflections on institutional reforms in the Department of Education. Human Development Network Discussion Paper Series, 2.

Behrman, J. R., Deolalikar, A. B., \& Soon, L.-Y. (2002). Promoting Effective Schooling through Education Decentralization in Bangladesh, Indonesia, and Philippines. ERD Working Paper Series, 23.

Bell, L., \& Stevenson, H. (2006). Education policy: Process, themes and impact. New York, NY: Routledge.

Bevir, M., \& Rhodes, R. (2003). Interpreting British governance. London: Routledge.

Bevir, M., \& Rhodes, R. (2006). Governance Stories. London: Routledge.

Bowe, R., Ball, S. J., \& Gold, A. (2017). Reforming Education and Changing Schools: Case studies in policy sociology (10th ed.). London: Routledge.

Brillantes, A. B. J. (1987). Decentralization in the Philippines: An overview. Philippine Journal of Public Administration, XXXI(2).

Capano, G., Howlett, M., \& Ramesh, M. (2015). Bringing Governments Back in: Governance and Governing in Comparative Policy Analysis. Institutions and Governance in Comparative Policy Analysis Studies (pp.27-37). London: Taylor \& Francis.

Cerna, L. (2014). Innovation, Governance and Reform in Education. Paper presented at the Innovation, Governance, and Reform in Education Conference, Paris, France.

Chapman, D. W. (2000). Trends in educational administration in developing Asia. Educational Administration Quarterly, 36(2), 283-308.

Cheng, Y. C., \& Tam, W. M. (1997). Multi-models of quality in education. Quality assurance in Education, 5(1), 22-31.

Cohen, W. M., \& Levinthal, D. A. (1990). Absorptive capacity: A new perspective on learning and innovation. Administrative Science Quarterly, 35(1) 128-152.

Corson, D. (1986). Policy in social context: A collapse of holistic planning in education. Journal of Education Policy, 1(1), 5-22.

Dale, R. (1997). The state and the governance of education: an analysis of the restructuring of the state-education relationship. In A.H Halsey, H. Lauder, P. Brown \& S. Wells (Eds.). Education Culture, Economy, Society. Oxford: Oxford University Press.

Daun, H. (2007). Globalization and the Governance of National Education Systems. In H. Daun (Ed.), School Decentralization in the Context of Globalizing Governance: International Comparison of Grassroots Responses (pp. 5-21). Dordrecht: Springer. 
De Guzman, A. B. (2007). Chronicling decentralization initiatives in the Philippine basic education sector. International Journal of Educational Development, 27(6), 613-624.

DepEd (2017). Number of Schools with Principal and Head Teachers. Department of Education

Diokno, B. E. (2008). Decentralization in the Philippines After Ten Years-What Have We Learned? In S. Ichimura \& R. Bahl (Eds.), Decentralization Policies in Asian Development (pp. 161-192). Kyoto: World Scientific.

Dixit, A. (2002). Incentives and Organizations in the Public Sector: An Interpretative Review. Journal of Human Resources, 37(4), 696-727.

Dolan, R. E. (1993). Philippines: A country study. Washington, DC: Federal Research Division.

Egalite, A. J., Fusarelli, L. D., \& Fusarelli, B. C. (2017). Will Decentralization Affect Educational Inequity? The Every Student Succeeds Act. Educational Administration Quarterly, 53(5), 757-781.

Fesler, J. W. (1968). Centralization and decentralization. International Encyclopedia of the Social Sciences, 2, 370-379.

Gerring, J. (2006). Case Study Research: Principles and practices. Cambridge: Cambridge University Press.

Grace, G. (1995). School Leadership: Beyond Education Management: An Essay in Policy Scholarship. Bristol, PA: Taylor \& Francis.

Han, S., \& Ye, F. (2017). China's education policy-making: a policy network perspective. Journal of Education Policy, 32(4), 389-413.

Hannaway, J., \& Woodroffe, N. (2003). Policy instruments in education. Review of Research in Education, 27(1), 1-24.

Harvey, L., \& Green, D. (1993). Defining quality. Assessment \& Evaluation in Higher Education, 18(1), 9-34.

Helgøy, I., \& Homme, A. (2006). Policy tools and institutional change: Comparing education policies in Norway, Sweden and England. Journal of Public Policy, 26(2), 141-165.

Hoy, C., Bayne-Jardine, C. C., \& Wood, M. (2000). Improving Quality in Education. London: Falmer Press.

Karlsen, G. E. (2000). Decentralized Centralism: Framework for a Better Understanding of Governance in the Field of Education. Journal of Education Policy, 15(5), 525-538.

King, E. M., \& Guerra, S. C. (2005). Education Reforms in East Asia: Policy, Process, and Impact. East Asia Decentralizes: Making Local Government Work, 179-208, World Bank Publication.

Kogan, M., \& Bowden, K. (1975). Educational policy-making: A Study of Interest Groups and Parliament. London: Allen \& Unwin.

Kooiman, J. (2000). Societal Governance: Levels, Models and Orders of Social-political Interaction. In J. Pierre (Ed.), Debating governance: Authority, steering, and democracy (pp. 138-164). Oxford: OUP.

Lapus, S. J. A. (2008). The Education System Facing the Challenges of the 21st Century. Age, 3(4), 5.

Levin, B. (2001). Conceptualizing the Process of Education Reform from an International Perspective. Education Policy Analysis Archives, 9(14).

Luz, J. M. (2009). The Challenge of Governance in a Large Bureaucracy (Department of Education): Linking Governance to Performance in an Under-Performing Sector. HDN Discussion Papers Series. Human Development Network,1. 
Magno, C. (2010). A Brief History of Educational Assessment in the Philippines. Educational Measurement and Evaluation Review, 1, 140-149.

Manasan, R. G., Cuenca, J. S., \& Celestino, A. B. (2011). Mobilizing LGU Support for Basic Education: Focus on the Special Education Fund. Brighton: Philippine Institute for Development Studies.

March, J. G. (1981). Footnotes to Organizational Change. Administrative Science Quarterly, 26(4)563577.

Mariñas, B. O., \& Ditapat, M. P. (1999). Philippines: Curriculum Development. In Globalization and Living Toghether: The Challenges for Educational Content in Asia (pp. 112-119). UNESCO- International Bureau of Education and Central Board of Secondary Education (India), Final Report on the Sub-regional Curriculum Development, New Delhi, March 9-17.

McDonnell, L. M., \& Elmore, R. F. (1987). Getting the Job done: Alternative policy instruments. Educational Evaluation and Policy Analysis, 9(2), 133-152.

Mintrom, M. (2001). Educational Governance and Democratic Practice. Educational Policy, 15(5), 615-643.

Monsod, T. C. (2009). The Philippine Bureaucracy: Incentive Structures and Implications for Performance. Human Development Network Discussion Paper Series, PHDR.

Myrdal, G. (1968). Asian Drama: An Inquiry into the Poverty of Nations. New York, NY: Twentieth Century Fund.

Ogundele, M. O., \& Laguador, J. M. (2017). Quality Assurance Mechanismsfor Sustainable Development of Nigerian and Philippine Education. Ghana and the Philippines: School Environment in Nigeria.

Orton, J. D., \& Weick, K. E. (1990). Loosely Coupled Systems: A reconceptualization. Academy of Management Review, 15(2), 203-223.

Ouimet, M., Bédard, P.-O., Turgeon, J., Lavis, J. N., Gélineau, F., Gagnon, F., \& Dallaire, C. (2010). Correlates of consulting research evidence among policy analysts in government ministries: a crosssectional survey. Evidence \& Policy: A Journal of Research, Debate and Practice, 6(4), 433-460.

Ozga, J. (2009). Governing Education Through Data in England: From Regulation to Self-Evaluation. Journal of Education Policy, 24(2), 149-162.

Paterson, L., \& Iannelli, C. (2007). Social Class and Educational Attainment: A comparative study of England, Wales, and Scotland. Sociology of Education, 80(4), 330-358.

Patrinos, H. A., Barrera-Osorio, F., \& Guáqueta, J. (2009). The Role and Impact of Public-Private Partnerships in Education. World Bank.

Patrinos, H. A., \& Fasih, T. (2009). Decentralized Decision-Making in Schools: The Theory and Evidence on School-Based Management. World Bank.

Petrosino, A., Morgan, C., Fronius, T., Tanner-Smith, E., \& Boruch, R. (2012). Interventions in Developing Nations for Improving Primary and Secondary School Enrollment of Children: A Systematic Review. Campbell Systematic Reviews, 8(19).

Philippines Comission on Audit. (2018). Government Assistance to Students and Teachers in Private Education (GASTPE): DepEd Promoted Greater Choice for Filipino Students Through the GASTPE Program but it Needs to Strengthen its Administrative Controls to Ensure Economy, Efficiency and Effectiveness of the Program Implementation. Retrieved from https://www.coa.gov.ph/index.php/gastpe-program?download=36165:governme nt-assistance-to-students-and-teachers-in-private-education-gastpe-program-pao-2018-02 
Presidential Commission to Survey Philippine Education. (1970). Education for National Development, New Patterns, New Directions. Philippines: Rizal.

Ranson, S. (1995). Theorizing Education Policy. Journal of Education Policy, 10(4), 427-448.

Reyes Jr, V. C. (2007). Corruption and policy implementation in the Philippines: A comparative analysis of the teacher training and textbook delivery programmes. Asian Journal of Political Science, 15(1), 97-125.

Reyes, V. C. (2009). Case study of implementation amidst corruption linkages: the National Textbook Delivery Program (TDP) of the Philippine Department of Education. Journal of Education Policy, 24(4), 515-535.

Rhodes, R. A.W. (2012). Waves of governance. In D. Levi-Faur (Ed.), The Oxford Handbook of Governance (pp. 33-48). Oxford: OUP.

Rivlin, A. M. (1973). Measuring performance in education. In The Measurement of Economic and Social Performance (pp. 411-437). NBER: NBER Book Series Studies in Income and Wealth.

Rondinelli, D. A. (1981). Government Decentralization in Comparative Perspective Theory and Practice in Developing Countries. International Review of Administrative Sciences, 47(2), 133-145.

Saguin, K. I. (2019). Designing effective governance of education. Policy Design and Practice, 2(2), 182-197.

Schleicher, A. (2019). PISA 2018: Insights and Interpretations. OECD Publishing.

Strunk, K. O., \& Grissom, J. A. (2010). Do Strong Unions Shape District Policies? Collective Bargaining, Teacher Contract Restrictiveness, and the Political Power of Teachers' Unions. Educational Evaluation and Policy Analysis, 32(3), 389-406.

Swanson, J. C. (1960). A Survey of the Public Schools of the Philippines-1960. Washington, DC: Clearinghouse.

Szolár, É. (2015). Change, Continuity And Path-Dependency in Hungarian Public Education. European Educational Research Journal, 14(3-4), 331-346.

Tan, C., \& Yang, J. (2019). Path-Dependency or Path-Shaping? An Analysis of The Policy to Target Exam-Orientation in South Korea. Critical Studies in Education, 1-16.

Tiongson, E. R. (2005). Education policy reforms. In A. Coudouel \& S. Paternostro (Eds.), Analyzing the Distributional Impact of Reforms (Vol. 1, pp. 261-294). The World Bank.

Torneo, A. (2016). Preliminary Assessment of the Impacts of the Performance Based Incentive System (PBIS) on the Philippine Department of Education: A Case Study of Employee Response to Policy Reform. Paper presented at the 2016 KAPS Autumn and International Conference, Olympic Parktel, Seoul, South Korea.

UNESCO. (1949). Report of the Mission to the Philippines. Paris: UNESCO.

Weick, K. E. (1976). Educational Organizations as Loosely Coupled Systems. Administrative Science Quarterly, 21, 1-19.

Weis, L. (1987). Introduction to "The Crisis in Teaching". Educational Policy, 1(1), 3-8.

Whitty, G. (2002). Making sense of education policy: Studies in the sociology and politics of education. London: PCP.

Wong, K. K. (1994). Linking governance reform to schooling opportunities for the disadvantaged. Educational Administration Quarterly, 30(2), 153-177. 
World Bank. (2011). Philippines Private Provision, Public Purpose: A Review of the Government's Education Service Contracting Program.

Retrieved from https://documents.worldbank.org/en/publication/documents-reports/documentdetail/486651468092652040/philippines-private-provision-public-purpose-a-review-of-the-governments-education-service-contracting-program

World Bank. (2014). Assessment of the Performance-based Bonus Scheme.

Retrieved from : https://documents.worldbank.org/en/publication/documents-reports/documentdetail/762401468057360902/philippines-improving-bureaucratic-performance-assessment-ofthe-performance-based-bonus-scheme

World Bank. (2018). World Development Report 2018: Learning to Realize Education's Promise. Retrieved from : https://www.worldbank.org/en/publication/wdr2018

World Bank, \& Asian Development Bank. (1999). Philippine education for the 21st century: the 1998 Philippines Education Sector Study. Manila: Asian Development Bank.

Yin, R. K. (2009). Case study research: Design and methods(4th ed.). Los Angeles and London: SAGE.

Zajda, J. (2003). Educational Reform and Transformation in Russia: Why Education Reforms Fail. European Education, 35(1), 58-88.

Zamora, M. D. (1967). Political History, Autonomy, and Change: The case of the Barrio Charter. Asian Studies, 5(1). 